\title{
The Cogeco Case: The First Preliminary Ruling on the Private Enforcement Directive ${ }^{\star}$
}

\author{
Catarina Vieira Peres ${ }^{* *}$
}

ABSTRACT: In March this year, the European Court of Justice (hereinafter "CJ") answered the first preliminary question regarding the Private Enforcement Directive ("Directive"). ${ }^{1}$ One might expect this decision ${ }^{2}$ to remain relevant for the next few years, as it sheds some light on the rather intricate issue of the Directive's temporal application. The CJ explains what rules are applicable to actions for damages regarding infringements which occurred prior either to the Directive's adoption or to its implementation in the respective Member States. The case is also of major interest since it illustrates the role that the principle of effectiveness can play when applied alongside Articles 101 or 102 of the Treaty on the Functioning of the European Union ("TFEU”). ${ }^{3}$ Finally, albeit not expressly addressed, the case is also of interest regarding the controversial issue of parent company liability in private enforcement, where it represents a novelty in the Portuguese legal order.

KEYWORDS: Damages Directive, private enforcement, temporal scope, limitation periods, principle of effectiveness

\footnotetext{
* Date of reception: 30 April 2019. Date of acceptance: 2 August 2019. DOI: https://doi.org/10.7559/mclawreview.2019.1827.

** Phd candidate at the Católica University, School of Law, Porto.

${ }^{1}$ Directive 2014/104/EU of the European Parliament and of the Council of 26 November 2014, on certain rules governing actions for damages under national law for infringements of the competition law provisions of the Member States and of the European Union, [2014] OJ L 349, 1-19.

${ }^{2}$ Judgment of 28 March 2019, Cogeco Communications Inc v. Sport TV Portugal SA et al., C-637/17, EU:C:2019:263.

${ }^{3}$ This case deals only with article 102 but the consequences that can be derived regarding the principle of effectiveness can also be applied to infringements of article 101.
} 


\section{Facts of the case}

In June 2013, the Portuguese Competition Authority ("PCA") adopted a decision ${ }^{4}$ holding that Sport TV Portugal, SA ("Sport TV"), a sports-oriented premium cable and satellite television network, had abused its dominant position through the practice of discriminatory prices, thereby simultaneously infringing $\mathrm{EU}^{5}$ and national competition law. ${ }^{6}$ This decision was adopted following a complaint filed in 2009 by Cabovisão - Televisão por Cabo, SA ("Cabovisão"), a company which offers subscription based television services in Portugal. At the time, Cabovisão was held by Cogeco Communications Inc. ("Cogeco"), a Canadian based company which exercised, directly or indirectly, exclusive control over the former.

In the appeal to the Portuguese Competition Court, ${ }^{7}$ Sport TV managed to get a partial annulment of the PCA's decision. According to this Court, the PCA was right in finding that Sport TV's conduct had infringed national competition law, but it held that there had been no violation of Article 102 TFEU, since the abusive conduct was not capable of affecting trade between Member States. This decision was confirmed by the Court of Appeal. ${ }^{8}$

In February 2015, Cogeco brought a follow-on action against Sport TV and its two joint-controlling shareholders demanding compensation for the damages suffered by its subsidiary, Cabovisão, as a result of Sport TV's anti-competitive practices.

In the meantime, in November 2014, the EU signed into law the Private Enforcement Directive, setting out rules to ensure that anyone who had suffered harm caused by an infringement of competition law could effectively exercise the right to claim full compensation for that harm. Member States had until the end of December 2016 to implement the Directive. Portugal failed to comply with this deadline and only transposed the Directive in June 2018, being the last Member State to do so. ${ }^{9}$

In the follow-on action brought by Cogeco, the defendants argued that under Portuguese civil law it could no longer demand compensation for

\footnotetext{
${ }^{4}$ Decision no. PCR-02/2010 of 14 of June 2013.

${ }^{5}$ Article 102 TFEU.

${ }^{6}$ Article 6 of Law no. 18/2003 of 11 of June, establishing the legal regime of competition. Diário da República no.134/2003, I-A of 2003-06-11.

${ }^{7}$ Tribunal da Concorrência, Regulação e Supervisão.

8 Judgment of Tribunal da Relação de Lisboa of 11 of March 2015, Cogeco Communications v. Sport TV et al., Proc. no. 5754/15.7T8LSB.

${ }^{9}$ Law 23/2018 of 6 June 2018, Diário da República no.107/2018, I of 2018-06-05.
} 
the harm suffered. It was time-barred from doing so since the applicable limitation-period had expired. Cogeco, relying on the Private Enforcement Directive, claimed it was still possible to seek damages since the limitation period had only begun to run after the PCA had published its decision fining Sport TV.

\section{The contentious issues: limitation periods, effects of administrative decisions and the temporal application of the Directive}

\section{(A) Limitation periods}

Limitation periods serve various different aims. First of all, they ensure legal certainty, reducing uncertainty to debtors, who would otherwise be constantly under the threat of being sued over a particular matter. They also have a practical justification: limiting the time to initiate legal action contributes to a more effective functioning of the judicial system. Limitation periods encourage potential creditors to start proceedings sooner rather than later, which will probably lead to fewer evidentiary difficulties. Furthermore, unsettled claims have a disturbing effect on trade, therefore limitation periods serve to minimise this effect by motivating parties to settle their disputes faster. ${ }^{10}$

Private enforcement of competition law brings its own set of challenges to limitation periods. ${ }^{11}$ These play a critical role in this context and are therefore one of the focal points of the Directive. Clear rules on prescription contribute to an optimal interaction between public and private enforcement. Uniform rules on limitation periods constitute a crucial component in the creation of an even European playing-field in actions for damages for competition law infringements. ${ }^{12}$

\footnotetext{
${ }^{10}$ Marian Hoeks, “Tick, Tock: Limitation Periods in Transport Law", European Journal of Commercial Contract Law 11 (2015): 11. Nathalie des Rosiers, "Canada", in Extinctive Prescription on the Limitation of Actions, ed. Ewoud Hondius (The Hague: Kluwer Law International, 1995), 94.

${ }^{11}$ Katri Havu, "Limitation periods in damages claims: Notes on a Finnish Supreme Court precedent in the context of the european landscape", Journal of European Competition Law and Practice 7, no. 6 (2016): 401. See also recital 36 of the Directive.

${ }^{12}$ Ana Vlahek and Klemen Podobnik, "Provisions of the Damages Directive on Limitation Periods and their implementation in CEE countries", Yearbook of Antitrust and Regulatory Studies 15 (2017): 149-150.
} 
The issue of limitation periods in private enforcement had already been addressed by the $\mathrm{CJ}$ in the Manfredi case..$^{13}$ In this preliminary ruling, adopted nearly a decade before the Directive, the Court had held that, in the absence of Community rules governing the matter, it was for each Member State to prescribe the limitation period for seeking compensation, provided that the principles of equivalence and effectiveness were observed. In this case, the Italian court had to decide whether a rule which provided that the limitation period started to run from the day on which the prohibited agreement or practice was adopted, and which imposed a short limitation period that could not be suspended, rendered it practically impossible or excessively difficult to exercise the right to seek compensation for the harm suffered. ${ }^{14}$

In Portuguese civil law, claimants have a period of three years to seek compensation for the damages suffered. According to the applicable rule - article 498 of the Portuguese Civil Code - the limitation period starts to run from the date on which the injured party was aware of its right to seek damages, regardless of whether it knew the identity of the infringer ${ }^{15}$ or the

\footnotetext{
${ }^{13}$ Judgment of 13 July 2006, Vincenzo Manfredi v. Lloyd Adriatico Assicurazioni, Antonio Cannito v. Fondiaria Sai and Nicolo Tricarico and Pasqualina Murgolo v. Assitalia, joined cases C-295/04 to C-298/04, EU:C:2006:461.

${ }^{14}$ Another recent case from Finland further illustrates the difficulty in determining when the limitation period to bring an action for damages starts to run and the role that the principles of effectiveness and equivalence play in that determination. This case, however, remained within the national jurisdiction, and was object of a preliminary ruling. In this case, the Finnish Act on Competition Restrictions established a 5 year limitation period to initiate damages proceedings from the date the injured party "knew or should have known the damage". The Helsinki District Court held that the limitation period had started to run when the Finnish Competition Authority had first published information on the investigations it was conducting on the cartel. The Helsinki Appellate Court overturned this decision since it considered that the limitation period only began to run when the Market Court adopted a final decision recognising the existence of an infringement of national and EU competition law. The Supreme Court did not agree with either of the other courts and decided that the timeframe had begun in-between, when the Finnish Competition Authority submitted a written proposal to the Market Court to impose a fine on the undertakings concerned for their involvement in the antitrust infringement. The Supreme Court considered that it was at this moment that the injured party had access to the information necessary to evaluate if he had suffered damages and the level of such damages and make a decision on whether compensation proceedings should be initiated. This interpretation assured that the national rules were aligned with the EU principles of effectiveness and equivalence. Havu, "Limitation Periods in Damages Claims".

${ }^{15}$ Regarding this issue the Portuguese regime is different from most of the other European tort law systems which require knowledge about the identity of the tortfeasor for the limitation period to start running. For instance, in Austria ( $\$ 1489$ Allgemeines bürgerliches Gesetzbuch), in Belgium
} 
total amount of damages suffered. Furthermore, there is no norm under Portuguese law specifically determining or authorising the suspension or interruption of the limitation period based upon the fact that the PCA is investigating the infringement to which the action for damages relates.

In contrast, article 10 of the Directive states that Member States are required to establish limitation periods with a minimum duration of five years, which cannot begin to run before the infringement has ceased ${ }^{16}$ and the claimant knows, or could reasonably be expected to know, (i.) about the behaviour and that it constitutes an infringement, (ii.) the fact that he or she has suffered harm due to infringement, and (iii.) the identity of the infringer. The Directive also demands the suspension or interruption of the limitation period while the competition authority is investigating or running proceedings in respect to the competition law infringement to which the action for damages relates.

\section{(B) Effects of administrative decisions}

Another issue under discussion in the case was the question of the effects of the decision of the competition authority. Prior to the implementation of the Directive, Portugal did not have a specific norm regulating this

(Article 2262bis of the Code Civil (inserted first in 1998 [L 1998-06-10/39]), in Croatia (Article 215 of the Civil Obligations Act), in the Czech Republic, in England (s. 11 of the Limitation Act 1980), in Germany (S199 Bürgerliches Gesetzbuch), in Greece (Article $937 \$ 1$ of the Civil Code), in the Netherlands (Article 3:310 Burgerlijk Wetboek); in Poland (Article 442: “\$1 of the Kodeks Cywilny) the limitation period will only start running from the moment the plaintiff has knowledge about the identity of the tortfeasor. However, in Spain and in France knowledge of the tortfeasor is dispensable. Whereas in other jurisdictions the limitation period starts to run when the damages occurs that is the case in Hungary (s6:22, s6:532, s6:533 of the Civil Code). Information obtained in André Pereira, "Limitation Periods - A Comparative Study", Boletim da Faculdade de Direito da Universidade de Coimbra 82 (2006): 587-590 and in Christian Salm, "Limitation periods for road traffic accidents", 2016, under "European Parliament", http://www.europarl.europa.eu/RegData/ etudes/STUD/2016/581386/EPRS_STU(2016)581386_EN.pdf.

${ }^{16}$ This reflects the Manfredi case law, where the CJ stated that "a national rule under which the limitation period begins to run from the day on which the agreement or concerted practice was adopted could make it practically impossible to exercise the right to seek compensation for the harm caused by that prohibited agreement or practice, particularly if that national rule also imposes a short limitation period which is not capable of being suspended". The Court added that, if the infringement was continuous or repeated, this could lead to a situation where the limitation period would expire before the infringement was brought to an end (judgment of 13 July 2006, Vincenzo Manfredi v. Lloyd Adriatico Assicurazioni, Antonio Cannito v. Fondiaria Sai and Nicolò Tricarico and Pasqualina Murgolo v. Assitalia, joined cases C-295/04 to C-298/04, EU:C:2006:461, paragraphs 78-79). See Vlahek and Podobnik, "Provisions of the Damages Directive on limitation periods", 155. 
issue; article 623 of the Portuguese Code of Civil Proceedings ('PCCP') was, therefore, applied by analogy. According to this norm, in civil proceedings where the consequences of an infringement are discussed, a final conviction given in a criminal case constitutes, in relation to third parties, a rebuttable presumption regarding the existence of such infringement. ${ }^{17}$ When transposed to competition law proceedings, this article has two possible interpretations: either (i.) no effects are attributed to the PCA's final infringement decision, as it is an administrative decision and not a criminal conviction or (ii.) the PCA's decision, as it has an analogous nature to criminal convictions, constitutes a rebuttable presumption, in relation to third parties, regarding the existence of the infringement.

However, Article 9 no. 1 of the Directive requires Member States to ensure that infringements of competition law found by a final decision of a national competition authority or by a review court are deemed to be irrefutably established for an action for damages brought before their national courts.

\section{(C) Temporal application of the Directive}

It is important to bear in mind that the case under analysis referred to a dispute between private parties regarding an infringement which took place before the Directive was signed into law and the claim for damages was lodged during the Directive's implementation period but prior to its transposition into the Portuguese legal order. In this regard, article 22 of the Directive provides that national measures adopted to comply with the substantive provisions of the Directive cannot be applied retroactively and no other national measures (i.e. procedural provisions) can be applied to actions for damages of which a national court was seized prior to 26 December 2014. When transposing the Directive, the Portuguese legislator stipulated that the substantive provisions contained in the implementation act, including those relating to the burden of proof, did not apply retroactively and the procedural provisions could not be applied to actions brought before the national act came into force. ${ }^{18}$

\footnotetext{
${ }^{17}$ To be more precise, article 623 states that the criminal conviction constitutes a rebuttable presumption "as regards the existence of the facts which satisfy the conditions for the imposition of a penalty and the elements of an offence".

${ }^{18}$ Article 24 of Law no. 23/2018.
} 
Faced with these contradictions, the Portuguese court decided to stay proceedings and ask the $\mathrm{CJ}$ what requirements are, in essence, imposed by EU law in actions for damages, between private parties, regarding infringements that occurred prior to the Directive's adoption and implementation.

\section{The applicability of Directive 2014/104: substantive vs. procedural rules}

The CJ limited its assessment to whether the Directive was applicable to the case ratione temporis, i.e. whether the temporal requirements of the Directive, foreseen in article 22, dictated its application to the case. Having reached a negative solution, the $\mathrm{CJ}$ considered it unnecessary to analyse the applicability of the Directive under the prism of its material requirements.

Nonetheless, it is interesting to take note of the Advocate-General's ("AG") comments on the applicability of the Directive ratione materiae. According to the AG, the Directive can only be relevant to the case if the national court decides that the abusive conduct constitutes an infringement of Article 102 TFEU. If, on the contrary, the national court comes to the conclusion that there was no violation of Article 102 TFEU, the Directive does not apply. This reasoning results from Articles 1 and 2 (1) and (3) of the Directive, which limit the material application of the Directive to infringements of EU Competition Law. According to these norms, the Directive only applies to infringements of national competition law if its provisions are applied to the same case and in parallel to EU competition law. Claims exclusively based in infringements of national competition law fall outside the scope of the Directive. The reason for this solution lies in the Directive's ultimate goal, which is to set rules fostering undistorted competition in the internal market and remove obstacles to its proper functioning. Only cases dealing with infringements that are capable of affecting trade between Member States are sufficiently related with the internal market. ${ }^{19}$

Regarding the application of the Directive ratione temporis, as mentioned above, article 22 prevents the retroactive application of the substantive measures of the Directive and determines that the procedural measures cannot be applied to actions for damages of which a national court

\footnotetext{
${ }^{19}$ Opinion of AG Kokott delivered on 17 January 2019, C-637/17, EU:C:2019:32, paragraphs 55-59.
} 
was seized prior to the date in which the Directive came into force. The aim of this norm is to ensure legal certainty. It strives to strike a balance between allowing injured parties' access to the reformed regime while not leaving defendants in an unfair position. ${ }^{20}$

However, the Directive does not specify which measures are of a procedural nature and which are substantive. This raises two questions: (i.) how do we qualify the nature of a norm? and (ii.) is qualification a matter to be solved by EU or by national law?

\section{(A) The legal nature of rules on limitation periods}

National legal orders around the world are strongly divided as regards the question of the nature of the norms on limitation periods. ${ }^{21}$ In Europe, rules on limitation periods are deemed, by most Member States, to be of a substantive nature, whereas in the UK, Bulgaria, Cyprus, the Czech Republic and Malta, limitation periods are considered to be procedural rules. $^{22}$ The difference between the legal regimes resides in the distinct conception of limitation periods. Under the civil law tradition, the course of time is generally considered to lead to the extinction of the substantive right, while in common law, the limitation period does not affect the existence of the right, but merely affects its exercise by the respective holder - it is therefore fundamentally seen as a question of procedure. ${ }^{23}$ In the words of Lord Sumption of the British Supreme Court, "limitation, which deprives the litigant of a forensic remedy but does not extinguish his right, is for that reason classified by the English courts as procedural". ${ }^{24}$

In Portugal, as a country of civil law tradition, norms on limitation periods are considered to have a substantive nature. In Portuguese civil law,

\footnotetext{
${ }^{20}$ See "Competition policy. Damages for breaches of Competition Law - Government response to consultation", Department for Business, Energy \& Industrial Strategy, 2016, accessed August 20, 2019, https://assets.publishing.service.gov.uk/government/uploads/system/uploads/attachment_data/file/577228/damages-directive-consultation-response.pdf.

${ }^{21}$ See Ernest Lorenzen, “The statute of Limitations and the conflict of Laws", The Yale Law Journal 28, no. 5 (1919): 492.

${ }^{22}$ Raúl Sánchez, "Law applicable to cross border road traffic accidents: Negative consequences resulting from the absence of harmonization of limitation periods and possible solutions", Anuario Español de Derecho Internacional Privado 18 (2018): 510-511.

${ }^{23}$ Raúl Sánchez, "Law applicable to cross border road traffic accidents", 510-511; Reinhard Zimmermann, Comparative Foundations of a European Law of Set-Off and Prescription (Cambridge: Cambridge University Press, 2002), 69-75.

${ }^{24}$ Judgment of the Supreme Court of 12 May 2016, Ministry of Defence v. Iraqi Civilians, [2016] UKSC 25, 2 .
} 
limitation periods are deemed to be part of the characteristics that inform the material legal relationship between creditor and debtor. They cannot be reduced to procedural requirements, since limitation rules determine the permanent cessation of a right. Limitation periods, in civil law, are therefore classified as a causa extintiva de direitos. ${ }^{25}$

The same can be said about limitation periods in the realm of Portuguese criminal law. They are also deemed to be part of substantive and not procedural law. ${ }^{26}$ Procedural norms express procedural requirements upon which the exercise of the judicial function depends. They ensure that decisions are adopted in a fair way and that unnecessary or useless decisions are avoided. Non-compliance with procedural requirements prevents the court from deciding on the merits or the substance of the case. Limitation periods do not fall under this classification. Instead, they are deemed to be a causa extintiva of criminal liability. In other words, the passage of time leads to the extinguishment of criminal liability. Even though limitation rules do not contribute to the definition or the delimitation of a criminal infringement, they affect the finding of criminal liability. Consequently, the principle of legality, in particular the non-retroactive application of criminal law, applies to norms regulating limitation periods.

Regarding the nature of norms on limitation periods under EU law, the $\mathrm{CJ}$ does not have an extensive decisional practice and has never, as far as we could find out, delved in depth in the analysis of this matter. A number of cases in the realm of state aid and tax law dealing with limitation

\footnotetext{
${ }^{25}$ This expression can be roughly translated as events leading to the cessation of rights. Carlos da Mota Pinto, Teoria Geral do Direito Civil (Coimbra: Coimbra Editora, 2012), 373; António Menezes Cordeiro, Tratado de Direito Civil (Coimbra: Almedina, 2011), 171-172; José Miguel Bezerra, Sampaio e Nora and João de Matos Antunes Varela, Manual de Processo Civil (Coimbra: Coimbra Editora, 2006), 297-298.

${ }^{26}$ In the words of José de Faria Costa, "legal rules regarding the expiry of the criminal procedure have mainly a material and not a procedural or adjective nature. This can be said principally because these norms by affecting, directly and invasively, the very personal sphere of the citizen and, in a certain way, as a result, some fundamental rights - such as the fundamental right to legal peace, among others - cannot be considered, by the very nature of things, as having a material nature" in José de Faria Costa, "O Direito Penal e o tempo", Direito 11, no. 1 (2002): 121. Figueiredo Dias also follows this dominant reasoning, however the author adopts a more hybrid approach as he draws a distinction between limitation rules regarding the criminal procedure and limitation rules regarding the extinction of the sanction. See Jorge de Figueiredo Dias, Direito Penal Português, As Consequências Jurídicas do Crime (Coimbra: Coimbra Editora, 2009), 700-701.
} 
periods for the recovery of unduly paid sums seem to point to the procedural nature of these rules.

The problem of determining the nature of legal norms has emerged where the EU judicature had to rule on the temporal application of the law, as "according to settled case-law, procedural rules are generally held to apply to all proceedings pending at the time when they enter into force, whereas substantive rules are usually interpreted as not applying, in principle, to situations existing before their entry into force". ${ }^{27}$ Substantive rules will only apply "to situations existing before their entry into force only in so far as it clearly follows from their terms, objectives or general scheme that such an effect must be given to them". ${ }^{28}$ As such, in Ireland and Aughinish Alumina v. Commission, ${ }^{29}$ for instance, the CJ held that Article 15 of Regulation No. 659/1999, which established a limitation period of 10 years for the Commission to exercise its powers to recover unlawful aid, ${ }^{30}$ was a procedural rule and, therefore, applicable from the time of that provision's entry into force. Even though, in this case, the aid had been granted before the entry into force of the relevant norm, the decision to recover that aid had the effect of starting the limitation period laid down in that article, as the decision had been taken after the entry into force of the article. ${ }^{31}$

\footnotetext{
${ }^{27}$ Judgment of 24 February 1987, Continentale Produkten Gesellschaft Ehrhardt-Renken v. Commission, Case 312/84, EU:C:1987:9423, paragraph 4; Judgment of 23 February 2006, Belgische Staat v. Molenbergnatie, C-201/04, EU:C:2006:136, paragraph 31; Judgment of 6 July 1993, CT Control (Rotterdam) and JCT Benelux v. Commission, joined cases C-121/91 and C-122/91, EU:C:1993:285, paragraph 22; Judgment of 7 September 1999, De Haan Beheer v. Inspecteur der Invoerrechten en Accijnzen te Rotterdam, C-61/98, EU:C:1999:393, paragraph 13; and Judgment of 14 November 2002, Ilumitrónica - Iluminação e Electrónica v. Chefe da Divisão de Procedimentos Aduaneiros e Fiscais/Direcção das Alfândegas de Lisboa, and Ministério Público, C-251/00, EU:C:2002:655, paragraph 29. See Juha Raitio, "Legal Certainty, Non-Retroactivity and Periods of Limitation in EU Law", Legisprudence 2, no. 1 (2008):11.

${ }^{28}$ Judgment of 12 November 1981, Amministrazione delle finanze dello Stato $v$ Srl Meridionale Industria Salumi et al.; Ditta Italo Orlandi \& Figlio and Ditta Vincenzo Divella v. Amministrazione delle Finanze dello Stato, joined cases 212 to 217/80, EU:C:1981:270, paragraph 9.

${ }^{29}$ Judgment of 22 of April 2016, Ireland and Aughinish Alumina v. Commission, joined Cases T-50/06 RENV II and T-69/06 RENV II, EU:T:2016:227, paragraphs 172-173.

${ }^{30}$ Council Regulation (EC) No. 659/1999 of 22 March 1999 laying down detailed rules for the application of Article 93 of the EC Treaty, [1999] OJ L 83, 1-9. This Regulation is no longer in force, it has been repealed and replaced by Council Regulation (EU) 2015/1589 of 13 July 2015 laying down detailed rules for the application of Article 108 TFEU, [2015] OJ L 248, 9-29. This Regulation also foresees a 10 year limitation period for the Commission to exercise its powers of recovery in article 17 , no. 1 .

${ }^{31}$ Under discussion in cases Aprile v. Amministrazione delle Finanze dello Stato (judgment of 17 November 1998, C-228/96, EU:C:1998:544) and Dilexport v. Amministrazione delle Finanze dello
} 


\section{When applying the abovementioned principle of temporal application of EU norms, the Court tends to affirm tout court that the norm at issue is of a procedural or substantive nature. The Court has never explained or developed criteria to justify why it considers that the relevant norms fall into a particular category. ${ }^{32}$}

Stato (judgment of 9 February 1999, C-343/96, EU:C:1999:59) was an Italian norm on the repayment of taxes recognised to be incompatible with Community law. The said norm reduced the limitation period to bring refund claims from 5 to 3 years. The CJ considered that the interpretation followed by Italian courts, which allowed proceedings to be instituted within the three years following the entry into force of the norm, could not be regarded as having retroactive effect (paragraph 28 in Aprile and paragraph 42 in Dilexport). Furthermore, in paragraph 42, the CJ specifically referred to the said norm as a "procedural rule". This reasoning was also applied in cases Marks \& Spencer v. Commissioners of Customs \& Excise (Judgment of 11 July 2002, C-62/00, EU:C:2002:435, paragraph 38) and Grundig Italiana v. Ministero delle Finanze (Judgment of 24 September 2002, C-255/00, EU:C:2002:525, paragraphs 36-38), where the CJ reaffirmed that national legislation which reduces the period within which repayment of sums collected in breach of Community law may be sought is not incompatible with the principle of effectiveness, as long as the new limitation period is reasonable, but also that the new legislation includes transitional arrangements allowing an adequate period after the enactment of the legislation for lodging the claims for repayment which persons were entitled to submit under the original legislation.

32 The International Court of Justice ("ICJ") has also drawn important consequences from the dichotomy of substantive v. procedural measures (see Jurisdictional Immunities of the State (Germany v. Italy: Greece intervening), Judgment, I.C.J. Reports 2012, p. 99). The ICJ has gone further than the $\mathrm{CJ}$ in trying to define both categories of norms, but the explanations remain quite brief. In Jurisdictional Immunities of the State, the ICJ stated that a rule which is procedural in nature "regulates the exercise of jurisdiction in respect of particular conduct and is thus entirely distinct from the substantive law which determines whether that conduct is lawful or unlawful". As commented by Stefan Talmon ("Jus Cogens after Germany v. Italy: Substantive and procedural rules distinguished", Leiden Journal of International Law no. 25, Bonn Research Papers on Public International Law, no. 4 (2012), https://ssrn.com/abstract=2085271), this is a too narrow understanding of procedural rules. Rules on jurisdiction certainly are one example of procedural rules, and the one that the ICJ was concerned with in this case, but these are not the only type of such rules.

Scholars have essentially developed three different tests to determine the nature of a norm. (i) A formal-functional test, which examines what the norm itself regulates. If it rules only the manner by which rights are exercised, it is of a procedural nature, if it alters the rules of the decision by which the court will attribute those rights, then it is substantive. (ii) An outcome-determinative test, which looks at the degree to which the rule affects the legal outcome and the litigants' rights. The rule will be deemed to have a substantial nature if it significantly affects the result of the litigation. (iii) A purposive test, which considers the purpose of the rule. The rule will be procedural if that is its aim, for example if it strives for adjudication efficiency or fact-finding accuracy, whereas the rule will be considered substantive if its aims relate to policy considerations and not to the administration of the legal process (Ofer Malcai and Ronit Levine-Schnur, "Which Came First, the Procedure or the Substance? Justificational Priority and the Substance - Procedure Distinction", Oxford Journal of Legal Studies 34, no. 1 (2014): 4. 
The famous Taricco saga, which deals with limitation periods in the context of criminal law, sheds some very interesting clues in this context.

The first Taricco case was a preliminary ruling initiated by the Italian Constitutional Court which raised the question of whether the rules of its criminal code on limitation periods prevented Italy from complying with its obligations flowing from Article 325 TFEU, which imposes on Member States the obligation to counter fraudulent or illegal activities affecting the financial interests of the EU. The Italian criminal code rules on limitation periods and their respective interruptions were rather lenient, which meant a de facto impunity of criminal agents of VAT fraud. ${ }^{33}$ The CJ considered that Italy would not be complying with its the obligations imposed by the Treaty if its national rules prevented the imposition of effective and dissuasive penalties in a significant number of cases of serious fraud affecting the financial interests of the $\mathrm{EU}$ or if the national norms violated the principle of equivalence by providing longer limitation periods regarding cases of fraud affecting national financial interests than regarding those affecting the financial interests of the EU. National courts were said to be under the obligation to give full effect to Article 325 by, need-be, disapplying said provisions of national law.

The CJ's decision was a source of major turmoil in the Italian legal order. Italian criminal rules on limitation periods are considered to have a substantive character. National courts doubted whether the disapplication of these rules, as required by the CJ's ruling, could signify a violation of the principle of legality, which requires criminal rules to be precise and prevents their retroactive application. ${ }^{34}$ The Constitutional Court therefore decided to refer another preliminary question asking, in essence, whether national courts, in criminal proceedings, are required to disapply national provisions on limitation periods when such disapplication entails a breach

\footnotetext{
${ }^{33}$ Specifically, Article 160 of the Italian Penal Code contained a rule according to which the limitation period could in no case be extended by more than a quarter of its initial duration. Given the complexity and duration of criminal proceedings in relation to value added tax offences, the rule had the effect of neutralising the temporal effect of an event interrupting the limitation period.

${ }^{34}$ The decision of the CJ in Tarico I also ran counter to previous case-law of the Italian Constitutional court, which had expressly held that limitation periods were substantive criminal norms and, therefore, the constitutional principle of non-retroactivity of criminal law applied to provisions regulating limitation periods. Matteo Bonneli, "The Taricco saga and the consolidation of judicial dialogue in the European Union: CJEU, C-105/14 Ivo Taricco and others, ECLI:EU:C:2015:555; and C-42/17 M.A.S., M.B., ECLI:EU:C:2017:936 Italian Constitutional Court, Order no. 24/2017", Maastricht Journal of European and Competition Law 25, no. 3 (2018), 361.
} 
of the principle of legality due to the lack of precision of the applicable law or due to its retroactive application. ${ }^{35}$

AG Bot was of the opinion that Italian courts had no choice but to disapply the national provisions. The AG argued that the concept of interruption of limitation periods had to be considered as an autonomous concept of EU law. By defining the principle of legality by reference to Article 49 of the Charter of Fundamental Rights of the EU, the AG came to the conclusion that the extension of limitation periods did not entail a violation of the rights of the defendant. The AG referred to the case-law of the European Court of Human Rights ("ECHR"), ${ }^{36}$ according to which the principle of legalit $y^{37}$ is satisfied when the individual can, from the relevant provisions, infer what acts or omissions will make him criminally liable. Restrictions on retroactivity apply only to norms which define criminal offences and the penalties imposed. Norms on limitation periods are of a procedural nature, therefore they can be applied immediately to pending proceedings.

The CJ did not follow the AG's opinion, choosing to follow a more conciliatory road. It started, however, by reiterating its decision in Tarico I, highlighting that national courts, in order to give full effect to their obligations under Article 325 TFEU, have to disapply norms - including those on limitation periods - which prevent the application of effective and dissuasive penalties needed to counter fraudulent activities affecting the financial interests of the EU. According to the CJ, it is the role of the legislator to devise rules enabling the respective Member State to comply with its obligations under the Treaty. In that regard, an extension of the limitation period, introduced by national legislation, and its immediate application does not - in principle - entail a violation of the principle of legality. However, when deciding to disapply rules of the national criminal code, Italian courts are required to ensure that the fundamental rights of the

\footnotetext{
${ }^{35}$ According to some authors, more than a clarification, the preliminary request was an attempt to avoid a constitutional collision between the two legal orders. Federico Fabbrini and Oreste Pollicino, "Constitutional identity in Italy: European integration as the fulfilment of the Constitution”, European University Institute Working Papers (2017): http://cadmus.eui.eu/bitstream/handle/1814/45605/LAW_2017_06.pdf?sequence=1\&isAllowed=y.

${ }^{36}$ Judgment of the ECHR of 22 June 2000, Coëme and Others v. Belgium, CE:ECHR:2000: 0622JUD003249296; judgment of the ECHR of 12 February 2013, Previti v. Italy, CE:ECHR:2013: 0212DEC000184508 and judgment of the ECHR of 22 September 2015, Borcea v. Romania, CE:ECHR:2015:0922DEC005595914.

${ }^{37}$ The principle of legality is foreseen in Article 7 of the European Convention for the Protection of Human Rights and Fundamental Freedoms.
} 
defendant are observed. National courts remain free to apply the national standards of protection of such rights, provided that the EU level of protection is not compromised.

The referring court argued that the principle of legality would be infringed if the provisions of the criminal code were disapplied in the current case since, before Tarico $I$, the defendant could not foresee that Article 325 TFEU required the court to disapply the limitation provisions. Furthermore, the Italian court considered that it was unable to define the particular circumstances in which it would have to disapply the national provisions, in accordance with the CJ's decision, without exceeding the limits imposed on its discretion.

After recalling the importance of the principle of legality attributed both by EU legal order and by the national legal systems of the Member States, the $\mathrm{CJ}$ considered that, since at the time of the main proceedings the rules on limitation periods regarding VAT fraud had not been harmonised by EU legislation, Italy was free to provide that rules on limitation periods formed part of its substantive law and were therefore subject to the principle that offences and penalties must be defined by law. The CJ then left to the national court the task of ascertaining whether the application of the Taricco I decision would lead to a situation of uncertainty, regarding the determination of the applicable limitation rules, which would amount to a violation of the principle of legality. If that were to be the case, the national court was not required to disapply the provisions of its criminal code, even if such disapplication would allow a national situation incompatible with EU law to be remedied. ${ }^{38}$

\section{(B) The legal nature of rules on the effects of administrative or judicial decisions}

Regarding the question of the nature of norms regulating the effects of administrative or judicial decisions, under Portuguese law they form part of what is called direito probatório (law of evidence). Direito probatório contains both substantive and procedural rules. Portuguese scholars tend to qualify as substantive norms relating to the burden, admissibility or value of proof, and as formal or procedural those that regulate how the

${ }^{38}$ The CJ also remarks that, in any case, the provisions of the Italian criminal code cannot be disapplied in relation to persons accused of committing VAT infringements before the delivery of the Taricco I judgement, otherwise they would be made retroactively subject to conditions of criminal liability stricter than those that were in force at the time that the infringement was committed. 
means of proof can be requested, submitted or presented in court. In order to avoid any doubts, the Portuguese legislator, in the act implementing the Directive, clearly stated that the rules relating to the burden of proof were to be considered as substantive rules. ${ }^{39}$

\section{(C) Nature of legal rules: a matter to be decided by EU or national law?}

In the AG's opinion, "the norms of articles 9 [effect of national decisions] and 10 [limitation periods] of Directive 2014/104, now under discussion, are not purely procedural rules" ${ }^{\prime 40}$. No justification was offered by the AG as to why norms on effects of decisions are of a substantive nature. Regarding the nature of rules on limitation periods, the AG, relying on the second Taricco decision, declared that since limitation rules had not been harmonised at the time, Portugal was free to qualify such rules as forming part of substantive law.

In our humble view, this is a weak spot in the AG's reasoning. Understandably, the Taricco saga casted a shadow over this decision; however, we believe that, regarding this specific point, the analogy with the Italian case is not entirely possible. Before we tackle the question of whether the modification of the limitation period, regarding the right to claim damages, violates the principle of legality, we have to decide whether the Directive is applicable to the case. In particular, it is necessary to determine what norms of the Directive can be applied retroactively and what norms the Directive prevents from applying retroactively. While it is true that, before the matter was harmonised, Portugal was free to determine the nature of its internal norms regulating the said issues, Portuguese legal order, or that of any other Member State, cannot play a role in determining the nature of the norms of the Directive itself.

Article 22 (1) of the Directive expressly refers to the national measures adopted to comply with the "substantive provisions of this Directive". In other words, what matters is not the nature of the national implementation measures, but the nature of the provisions of the Directive. The qualification of these norms as procedural or substantive is logically a matter to be decided by EU law. It makes no sense to leave this qualification to the internal legal order of the various Member States, which will inevitably

\footnotetext{
${ }^{39}$ Article 24 of Law 23/2018 of 6 of June 2018.

${ }^{40} \S 61$.
} 
offer distinct and incompatible answers, thereby affecting the harmonisation aims of the Directive, at least during a significant period of time.

Admittedly, the problem resides in the equivocal wording of Article 22. Interpretative doubts could have been avoided if, instead of merely referring to the "procedural and substantive" provisions of the Directive, the EU legislator had listed the norms that were to be applied retroactively.

Predictably, when transposing the Directive, Member States did not take into account EU case-law (which in any case is scarce and not entirely clear) to decide which norms of the Directive were capable of retroactive application. Instead, most Member States merely replicated the wording of Article 22 or adopted very similar ambiguous provisions. In practice, this means that each national legal order will use its internal legal methods to interpret the nature of the norms of the Directive, leading to a high level of hidden heterogeneity in the transposition measures, reducing transparency and generating legal uncertainty. ${ }^{41}$ Furthermore, many Member States have specified the temporal scope of all or some of the provisions of the new regime in ways that contradict each other or the EU judicature's case law. ${ }^{42}$

As commented by Rodger, B. et al, the Directive's temporal scope "proved to be one of the most divisive issues in the transposition of the Directive", as the broad and imprecise drafting of the norm provides "limited useful guidance". ${ }^{43}$ According to the authors, uniformity in the application of EU law regarding this matter can only be achieved if the CJ intervenes, through preliminary rulings, to impose a harmonious interpretation. On the contrary, if the Court followed the AG's suggestion and left to the MS the qualification of the Directive's norms according to their legal traditions, it would only be adding ambiguity to an already unclear rule.

Making matters worse, the problem of determining the nature of the norms does not concern limitation periods only. The nature of the rules on the effect of national decisions is also not clear. And even though they were not at issue in this particular case, interpretative doubts regarding the temporal application of the Directive might also arise in relation to

\footnotetext{
${ }^{41}$ Barry Rodger, Miguel Sousa Ferro and Francisco Marcos, "Transposition context, process, measures and scope", in The EU Antitrust Damages Directive Transposition in the Member States, ed. Barry Rodger, Miguel Sousa Ferro and Francisco Marcos (Oxford: Oxford University Press, 2018), 434.

${ }^{42}$ Ibidem, 434.

${ }^{43}$ Ibidem, 433.
} 
norms dealing with disclosure of evidence and consequences for failing to cooperate with national courts, jurisdictional provisions, as well as other rules dealing with the burden of proof. ${ }^{44}$

The CJ's decision in Cogeco, however, does not provide us with a universal solution, as envisaged by the abovementioned authors, capable of being applied in all jurisdictions and drawing to a halt any interpretive doubts that may arise regarding the Directive's temporal scope. The decision in Cogeco is rather an ad hoc clarification, tailored to the specific case of the Portuguese legal order. The CJ, instead of providing a decisive answer on the nature of the norms on limitation periods, artfully adopted a decision which managed to avoid this prickly question altogether. According to the $\mathrm{CJ}$, the Directive was not, in any event, applicable ratione temporis to the dispute in the main proceedings. ${ }^{45}$ If the norms of the Directive on limitation periods were to be considered as substantive norms, they could not be applied to the case, since the Directive prevents their retroactive application. ${ }^{46}$ But the same conclusion would be reached if the norms were considered to be procedural in nature. This is because Article 22 (2) precludes the application of procedural norms to actions for damages lodged before the Directive came into force. This means that "Member States enjoyed a measure of discretion in deciding, when transposing that directive, whether the national rules intended to transpose the directive's procedural provisions would apply to actions for damages brought after 26 December 2014 but before the date of transposition of that directive or, at the latest, before the expiry of the period prescribed for its transposition".

According to the Portuguese implementation act, procedural norms are not applicable to cases where the court was seized prior to the date in which the Portuguese implementing act came into force, ${ }^{47}$ which only happened in August 2018. Cogeco's action for damages was brought on

\footnotetext{
${ }^{44} \mathrm{Ibidem}, 434-435$. For instance, whereas in general, rules on presumptions are seen as procedural in nature (see Aistė Mickonyte, Presumption of Innocence in EU Anti-Cartel Enforcement (Leiden: Brill Nijhoff, 2019), 6) and the CJ has qualified them as such (see Judgment of 18 December 2014, CA Consumer Finance v. Ingrid Bakkausburden et al., C-449/13, EU:C:2014:2464, paragraphs 22-23, where the Court qualified as procedural a rule dealing with the burden of proof that the creditor had fulfilled its obligations), Portugal, in its implementation act, specifically refers to rules on the burden of proof as substantial (see Article 24 no. 1 of Lei 23/2018 of 6 June 2018).

$45 \$ 33$.

${ }^{46} \$ 26$ and 30 .

${ }^{47}$ Article 24 (2) of Law 23/2018.
} 
February 2015, before the expiry of the deadline to transpose the Directive and before its transposition into the Portuguese legal order. Thus, logically, the procedural norms also fail to apply ratione temporis.

\section{The Portuguese limitation period and the principle of effectiveness}

The Directive was deemed to be inapplicable to the case, but the CJ still had to address the question of the compatibility of a norm such as Article 498 no. 1 of the Portuguese Civil Code with EU law, in particular with Article 102 TFEU and the principles of effectiveness and equivalence.

As mentioned above, Article 498 of the Civil Code establishes a three year limitation period which starts regardless of whether the claimant knows the identity of the infringer or the total extension of the damages, and there is no specific norm foreseeing the possibility of suspending or interrupting the limitation period for the duration of proceedings following which a final decision is made by the national competition authority or by a review court.

To answer this question, the CJ started by recalling that Article 102 produces direct effect in relations between individuals. Furthermore, the full effect of Article 102 would be compromised if anyone who has suffered damages from an abuse of dominant position could not exercise their right to claim damages. Since the Directive was inapplicable, it is for the domestic legal system to regulate the exercise to claim damages, in observance with the principles of effectiveness and equivalence.

It is clear that Article 498 of the Civil Code does not disregard the principle of equivalence since it is applicable to claims for damages regardless of whether they result from an infringement of national or EU competition law. But its compatibility with the principle of effectiveness is more problematic. $^{48}$

The principle of effectiveness dictates that national rules cannot render the exercise of an EU right impossible or excessively difficult. In this case, they cannot jeopardise the effective application of Article 102. In order to decide if this was the case, the CJ deemed necessary to take into consideration all the elements of the Portuguese limitation rules.

The CJ did not specifically address the matter of whether a limitation period of three years - solely on account of its duration - infringes the

${ }^{48} \$ 54$. 
principle of effectiveness. The AG, however, affirmed that a norm establishing a limitation period of three years did not violate the said principle. The AG considered it to be a sufficiently long delay for the claimant to exercise his right. A limitation period of three years did not render the exercise of such right impossible or excessively difficult.

What the CJ considered more problematic was the fact that the limitation period starts to run before the injured person is able to ascertain the identity of the infringer ${ }^{49}$ and the fact that the limitation period cannot be suspended or interrupted for the duration of proceedings before the national competition authority or the review court. ${ }^{50}$ The CJ came to the conclusion that "a limitation period of three years [...], which, first, starts to run from the date on which the injured party was aware of its right to compensation, even if the infringer is not known and, secondly, may not be suspended or interrupted in the course of proceedings before the national competition authority, renders the exercise of the right to full compensation practically impossible or excessively difficult". ${ }^{51}$

\section{Irrelevance of the question on effects of decisions}

Regarding the question of compatibility with Article 102 and the principle of effectiveness of a norm, such as the Article 623 of the PCCP, on the effects of a definitive decision of the national competition authority, the AG had held that the exercise of the right to claim damages would be rendered extremely difficult if no effects were attributed to an infringement decision of the competition authority. According to the AG, considering the complexity of competition law infringements and the difficulties the claimant faces to prove them, the principle of effectiveness dictates that definitive infringement decisions of the competition authority have to serve, at least, as an indicator regarding the existence of the respective infringement. ${ }^{52}$ The principle of effectiveness does not, however, require

\footnotetext{
${ }^{49}$ According to the AG, even though it is indispensable to know the identity of the infringer to bring a successful action for damages, this task is frequently more complex in the realm of competition law, where infringers are usually legal persons who are members of complex corporate groups hardly comprehensible for the external observer. $\$ 84$ of the Opinion.

${ }^{50} \mathrm{On}$ this issue, the AG points to the fact that a correct legal appreciation of a competition law infringement involves, very frequently, the analysis of complex economic situations and internal commercial documents which are brought to light through the investigation carried out by the competition authorities. $\$ 85$ of the Opinion.

${ }^{51} \S 53$.

${ }^{52} \$ 93$.
} 
the attribution of binding effects to the final decisions of the competition authority. Accordingly, an interpretation of Article 623 PCCP that does not recognise any effects to a final infringement decision of the PCA is incompatible with the principle of effectiveness, but an interpretation of Article 623 of the PCCP, which considers that decisions of the competition authority create a rebuttable presumption regarding the existence of an infringement, are not incompatible with Article 102 TFEU and the principle of effectiveness.

The CJ, however, refused to rule on this question. As described above, the decision of the PCA was partially annulled by the Competition Court on the grounds that the defendant had not infringed Article 102 TFEU, and this decision was confirmed by the Court of Appeal. This means that the subject matter in the main proceedings is not an action for damages following a final decision finding an infringement of Article 102 TFEU. The question was thus considered inadmissible since the interpretation of the principle of effectiveness and the Treaty and their compatibility with national legislation bore no relation to the actual facts in the main action. ${ }^{53}$

\section{Implications of the CJ's decision in the main proceedings}

Notwithstanding the CJ's conclusion that a norm such as Article 498 of the Civil Code could render the exercise of the right to claim compensation for damages caused by EU competition law infringements impossible or excessively difficult, the limitation period foreseen in the article might still be applicable by the national court to the case at hand.

First of all, it remains to be decided if there was an infringement of Article 102 TFEU. If the national court finds that the plaintiff's abusive conduct was not capable of affecting trade between Member States, and there is therefore only an infringement of national competition law, there is no reason not to apply the limitation regime foreseen in Article 498 of the Civil Code in its integrity. The CJ's ruling only applies if there was an infringement of Article 102 TFEU. It is clear from the wording of the CJ's decision that the principle of effectiveness does not dictate this solution if the case is restricted to the realm of national competition law.

Secondly, in this case, at least at a first glance, there seem to be no problems regarding the identification of the infringer. The PCA initiated its investigation after a complaint against the conduct of Sport $T V$ was filed

\footnotetext{
${ }^{53}$ Paragraphs 56-60.
} 
by Cabovisão, a wholly-owned subsidiary of Cogeco. It seems therefore highly likely that Cogeco knew who the infringer was from the outset of the infringement period. The case deals with an abuse of dominant position stemming from a distribution contract signed between the two parties. Furthermore, in cases of abusive conduct, by definition, the infringer can be no other than the company holding the dominant position. There were also no issues of succession, transmission or complex group restructurings that could leave the injured party in doubt about the infringer's identity.

Finally, while it is true that in the Portuguese legal order there is no norm specifically foreseeing the suspension or the interruption of the limitation period during proceedings before the national competition authority, it is possible, through a mechanism called "notificação judicial avulsa", to interrupt the limitation period. This mechanism, established in Article 323 of the Portuguese Civil Code, allows the creditor to interrupt the limitation period through a judicial notification or writ expressing the creditor's intention to exercise his right in the future.

In conclusion, even if the national court finds that there was an infringement of Article 102 TFEU, it should still be able to apply the limitation rules foreseen in the Portuguese Civil Code, since, in this specific case, the principle of effectiveness does not seem capable of hampering their application.

\section{A brief comment on parent company liability}

This case warrants some comments on the controversial problem of parent company liability, even though this issue does not form part of the contentious matter before the courts.

In EU competition law undertakings are defined as economic, rather than legal, units. Accordingly, the scope of an undertaking does not necessarily coincide with that of a legal entity. An undertaking might not have legal personality or it might be composed of several natural or legal persons. In practical terms, this means that a parent company might be held liable for an infringement committed by a subsidiary, if they are deemed to form part of the same single economic entity. The crucial criterion to determine whether several entities form a single undertaking is whether these entities display a unified conduct on the market. According to settled EU case-law, attribution of liability to a parent company for an infringement committed by a subsidiary depends on the fulfilment of two conditions: 
(i) the parent company is in a position that enables it to exercise decisive influence and (ii) decisive influence was in fact exercised. ${ }^{54}$

In Portugal, even though the Portuguese Competition $\mathrm{Act}^{55}$ defines "undertaking" according to EU case-law, recognising that an undertaking might comprise different legal entities, ${ }^{56}$ the PCA, prior to the Directive's implementation, tended to apply fines only to the subsidiaries who were directly involved in the infringement, rather than to their parent companies, even when the entities constituted a single undertaking. ${ }^{57}$ The PCA's choice to fine only the subsidiaries seemed to be based on policy considerations and resulted from the national courts' refusal in attributing vicarious liability to parent companies. National courts, which hold very conservative views, prefer to rely on internal doctrines of criminal law regarding the concept of infringer and the principle of non-transmissibility of guilt. ${ }^{58}$

Despite, or perhaps due to, the jurisdictional reluctance to apply the EU concept of economic unit and parent company liability, the PCA ${ }^{59}$, when drafting the transposition proposal of the Private Enforcement Directive, introduced a provision establishing the civil liability of the undertaking as a single economic unit.

\footnotetext{
${ }^{54}$ On the subject see Alison Jones, "The boundaries of an undertaking in EU competition law", European Competition Journal 8, no. 2 (2012): 301-331; Andriani Kalintri, "Revisiting parental liability in EU competition law”, European Law Review 43, no. 2 (2018): 145-166; Okeoghene Odudu and David Bailey, "The single economic entity in EU competition law", Common Market Law Review 51 (2014): 1721-1758; Stefan Thomas, "Guilty of a fault that one has not committed. The limits of the group-based sanction policy carried out by the Commission and the European courts in EU-antitrust law", Journal of European Competition Law \& Practice 3, no. 1 (2012):11-28; Wouter Wils, "The undertaking as subject of E.C. competition law and the imputation of infringements to natural or legal persons", European Law Review 25, no. 2 (2000): 99-116.

${ }^{55}$ Law 19/2012 of 8 of May, Diário da República no. 89/2012, I of 2012-05-08.

${ }^{56}$ Article 3 no. 2 of the Portuguese Competition Act: "A group of undertakings is deemed to be a single undertaking, even if the undertakings themselves are legally separate entities, where such undertakings make up an economic unit or maintain interdependence ties deriving specifically from the following: a) The undertaking so defined has a majority of the share capital; b) It has more than half of the voting rights conferred by the share capital; c) It has the power to appoint more than half of the members of the board of directors or the supervisory board; d) It has the necessary powers to manage the businesses of the group and of each of its undertakings".

${ }^{57}$ Ana de Oliveira and Miguel Sousa Ferro, "The sins of the son: Parent company liability for competition law infringements", Revista da Concorrência e Regulação 1, no. 3 (2010): 75.

${ }^{58}$ Tribunal de Comércio de Lisboa, 2 of May 2007, 965/06.9TYLSB; Tribunal da Concorrência, Regulação e Supervisão, 20 of October 2016, 45/13.OYUSTR; Tribunal da Relação de Lisboa, 14 of June 2017, 36/16.0YUSTR.L1.

${ }^{59}$ In Portugal, the Ministry of Economy entrusted the drafting of the transposition proposal to the PCA. See Article 3 of Portuguese Act implementing the Private Enforcement Directive
} 
Interestingly, in this case, the EU concept of undertaking is applied to both sides of the dispute. Regarding the defendant, even though the decision of the PCA was solely addressed to Sport $T V$, the action for damages was also filed against its shareholders (Controlinvest-SGPS, SA and NOS$S G P S, S A)$. Regarding the injured party, the company that directly suffered damages was the subsidiary - Cabovisão, nonetheless, the main proceedings were initiated by its parent company - Cogeco, who is thereby relying on the EU concept of undertaking. The question then arises whether Cabovisão can initiate its own claim for damages regarding this same infringement or whether this represents a violation of the principle of non bis in idem. ${ }^{60}$

\section{Concluding remarks}

The CJ ruling in Cogeco does not fully eliminate all the interpretative doubts regarding the Directive's temporal application. This decision does not put an end to all the potential uncertainties that can stem from the ambiguous and unclear wording of Article 22 of the Directive. It is therefore possible that in the next few years there will be more preliminary rulings, not only in relation to limitation periods regarding infringements that occurred before the Directive entered into force, but also regarding other norms whose nature is not entirely clear or which are heterogeneously qualified by the different Member States.

Furthermore, even if there are no doubts regarding its temporal applicability, authors have pointed out that the Directive does not solve interpretation issues regarding limitation periods completely. There are, in particular, difficulties in determining when the claimant can reasonably be expected to know about the subjective conditions that trigger the limitation period. When should the conditions for such legal fiction be considered as actually fulfilled? Is it (i) when the media publishes news about the infringement; (ii) when the competition authority initiates its inquiry; (iii) when the competition authority publishes the statement of objections or the infringement decision; (iv) or the moment when that decision can no longer be appealed? ${ }^{61}$ And the determination of this moment is even more

\footnotetext{
${ }^{60}$ In fact, Cabovisão has initiated an action for damages against Sport TV but the proceedings are currently suspended awaiting the final decision in the Cogeco case.

${ }^{61}$ Vlahek and Podobnik, "Provisions of the Damages Directive on Limitation Periods": 156-157.
} 
difficult in cases where there was no public enforcement activity. ${ }^{62}$ It will be interesting to see how national courts handle this issue.

In terms of the impact of the Court's ruling in this particular case, as we have seen, everything will depend on whether the national court decides to apply Article 102 TFEU to the case. And even if it decides so, the general limitation period foreseen in the Portuguese Civil Code might still apply since, in this particular case, there were no issues regarding the identification of the infringer and it was actually possible to interrupt the limitation period. We are also curious to see whether the Portuguese court will unprecedentedly accept to impute liability to the parent companies for an abuse of dominant position committed by their subsidiaries or whether it will uphold the defendant's plea regarding the lack of locus standi of the parent companies.

\section{Bibliography}

Bezerra, José Miguel, Sampaio e Nora and João de Matos Antunes Varela. Manual de Processo Civil. $2^{\text {nd }}$ ed. Coimbra: Coimbra Editora, 2006.

Bonneli, Matteo. "The Taricco saga and the consolidation of judicial dialogue in the European Union: CJEU, C-105/14 Ivo Taricco and others, ECLI:EU:C:2015:555; and C-42/17 M.A.S., M.B., ECLI:EU:C:2017:936 Italian Constitutional Court, Order no. 24/2017". Maastricht Journal of European and Competition Law 25, no. 3 (2018): 357-373.

Des Rosiers, Nathalie. "Canada”. In Extinctive Prescription on the Limitation of Actions, edited by Ewoud Hondius, 93-113. The Hague: Kluwer Law International, 1995.

Fabbrini, Federico and Oreste Pollicino. "Constitutional identity in Italy: European integration as the fulfilment of the Constitution". European University Institute Working Papers (2017). http://cadmus.eui.eu/bitstream/handle/1814/45605/LAW_2017_06. pdf?sequence $=1$ \&isAllowed $=\mathrm{y}$.

Faria Costa, José de. "O Direito Penal e o tempo". Direito 11, no. 1 (2002): 109-132.

Figueiredo Dias, Jorge de. Direito Penal Português, As Consequências Jurídicas do Crime. $2^{\text {nd }}$ ed. Vol. II. Coimbra: Coimbra Editora, 2009.

Havu, Katri. "Limitation periods in damages claims: Notes on a Finnish Supreme Court precedent in the context of the European landscape". Journal of European Competition Law and Practice 7, no. 6 (2016): 401-406.

Hoeks, Marian. “Tick, tock: Limitation periods in transport law”. European Journal of Commercial Contract Law, 11 (2015): 7-20.

\footnotetext{
${ }^{62} \mathrm{Havu}$, "Limitation periods in damages claims": 406.
} 
Jones, Alison. "The boundaries of an undertaking in EU competition law". European Competition Journal 8, no. 2 (2012): 301-331.

Kalintiri, Andriani. "Revisiting parental liability in EU competition law". European Law Review 43, no. 2 (2018): 145-166.

Lorenzen, Ernest. "The statute of limitations and the conflict of laws". The Yale Law Journal 28, no. 5. (1919): 492-498.

Malcai, Ofer and Ronit Levine-Schnur. "Which came first, the procedure or the substance? Justificational priority and the substance-procedure distinction". Oxford Journal of Legal Studies 34, no. 1 (2014): 1-19.

Menezes Cordeiro, António. Tratado de Direito Civil. $4^{\text {th }}$ ed. Coimbra: Almedina, 2011.

Mickonyte, Aistè. Presumption of Innocence in EU Anti-Cartel Enforcement. Leiden: Brill Nijhoff, 2019.

Mota Pinto, Carlos. Teoria Geral do Direito Civil. $4^{\text {th }}$ ed. Coimbra: Coimbra Editora, 2012.

Odudu, Okeoghene and David Bailey. "The single economic entity in EU competition law”. Common Market Law Review 51 (2014): 1721-1758.

Oliveira, Ana de and Miguel Sousa Ferro. "The sins of the son: Parent company liability for competition law infringements". Revista da Concorrência e Regulação 1, no. 3 (2010): 53-92.

Pereira, André. "Limitation periods - A comparative study". Boletim da Faculdade de Direito da Universidade de Coimbra 82 (2006): 583-612.

Raitio, Juha. "Legal certainty, non-retroactivity and periods of limitation in EU law". Legisprudence 2, no. 1 (2008): 1-24.

Rodger, Barry, Miguel Sousa Ferro and Francisco Marcos. “Transposition context, process, measures and scope". In The EU Antitrust Damages Directive Transposition in the Member States, edited by Barry Rodger, Miguel Sousa Ferro and Francisco Marcos, 411-439. Oxford: Oxford University Press, 2018.

Salm, Christian. "Limitation periods for road traffic accidents". European Parliament. 2016. http://www.europarl.europa.eu/RegData/etudes/STUD/2016/581386/ EPRS_STU(2016)581386_EN.pdf.

Sánchez, Raúl. "Law applicable to cross border road traffic accidents: Negative consequences resulting from the absence of harmonization of limitation periods and possible solutions”. Anuario Espanol de Derecho Internacional Privado 18 (2018): 493-530.

Talmon, Stefan. "Jus Cogens after Germany v. Italy: Substantive and procedural rules distinguished". Leiden Journal of International Law no. 25, Bonn Research Papers on Public International Law no. 4 (2012): https://ssrn.com/abstract=2085271.

Thomas, Stefan. "Guilty of a fault that one has not committed. The limits of the groupbased sanction policy carried out by the Commission and the European Courts 
in EU-antitrust law". Journal of European Competition Law \& Practice 3, no. 1 (2012):11-28.

Vlahek, Ana and Klemen Podobnik. "Provisions of the Damages Directive on Limitation Periods and their implementation in CEE countries". Yearbook of Antitrust and Regulatory Studies, 15 (2017): 147-176.

Wils, Wouter. "The undertaking as subject of E.C. competition law and the imputation of infringements to natural or legal persons". European Law Review 25, no. 2 (2000): 99-116.

Zimmermann, Reinhard. Comparative Foundations of a European Law of Set-Off and Prescription. Cambridge: Cambridge University Press, 2002. 